\title{
Hepatitis C Among Blood Donors In A Teaching Hospital In North Central Nigeria
}

\author{
*Nwannadi Ikenna Alexander, *Alao Olusayo, *Shoaga Lanre \\ *Department of Haematology and Blood Transfusion Benue State University Teaching Hospital, Makurdi, \\ Nigeria
}

\begin{abstract}
Background:A regional monitoring system for Hepatitis $C$ virus infection could provide a crucial tool for revealing changes in the pattern of the disease in the community. Our aim was to determine the prevalence of Hepatitis $C$ infection among blood donors in our blood transfusion service department.

Materials and Methods: A retrospective review of 1241 donors over a period of 17 months (March 2012- July 2013) was carried out. Data collected was analyzed with SPSS version 19. Prevalence of Hepatitis C was expressed in percentages. Associations of Hepatitis $C$ infection with socio-demography, haematocrit and donor type were checked with Chi-square.

Results: The 1241 donors were made up of 1158 (93.3\%) males and 83 (6.7\%) females. Ninety-eight percent (1216) were replacement donors while $2 \%$ (25) were voluntary donors. The overall prevalence of Hepatitis $C$ infection was $4.1 \%(n=51)$. Hepatitis $C$ infection was significantly high $1.7 \%(n=21)$ in donors aged 30-41 years. Hepatitis $C$ seropositivity was more in males $46(3.7 \%)$, blood group $O$ Rhesus positive $3.3 \%(n=41)$, and in donors with haematocrit between 43-50\%, 31 (2.5\%). Family replacement donors had Hepatitis C infection rate of $50(4.0 \%)$ while voluntary donor accounted for $1(0.1 \%)$.

Conclusion: The risk of acquiring Hepatitis $C$ infection is high if blood is not screened for Hepatitis $C$ antibody in the study centre. This risk can be reduced by using more sensitive methods for Hepatitis $C$ screening.
\end{abstract}

\section{Introduction}

Hepatitis $\mathrm{C}$ is a major public health problem in developing countries.1 It has been reported that about $3.0 \%$ of the world population is infected with HCV.2 The virus is a positive sense single stranded RNA virus. Its genome consists of a single open reading frame that is 9600 nucleotide bases long. 3 It is a major cause of liver cirrhosis and hepatoma with significant morbidity and mortality.4 The common means of transmission is through infected blood and body fluid, use of infected sharp objects and sexual intercourse. As a result, the WHO included the screening for HCV antibodies as one of the four mandatory screening tests in blood donors. The various means of reducing the spread of these infections through blood transfusion include careful donor selection, routine screening of blood donors for HCV antibodies, irradiation of blood components, and judious clinical use of blood. The epidemiology of this disease has been widely studied, even in Nigerian but as a new institution no study has been carried out on the risk of HCV in blood donors in the study centre. We therefore embarked on this study to establish the prevalence of Hepatitis $\mathrm{C}$ and provide a baseline data in this new institution.

\section{Materials And Methods}

This study was carried out at the Haematology Department of the Benue State University Teaching Hospital, Makurdi. Approval was given for the study. A retrospective review of 1241 donors over a period of 17 months (March 2012- July 2013) was carried out. All individuals who presented themselves for blood donation during this period were included in the study. Data on socio-demography, blood group, packed cell volume (PCV) and results of HCV screening were retrieved from the donor register. Screening of the donors was done with rapid test kit. The kit tested for the presence of the antibodies to the infective agent in donor plasma. The rapid test kit had a sensitivity of $96.6 \%$ and specificity of $99.5 \%$. The data were collated and analyzed with SPSS version 19. Prevalence of $\mathrm{HCV}$ antibodies was expressed in percentages. Associations of $\mathrm{HCV}$ seropositivity with demography, PCV and blood groups were checked with Chi-square. P-value less than 0.05 was regarded as statistically significant.

\section{Results}

A total of 1241 donors presented themselves for blood donation during the study period. They were made up of $1158(93.3 \%)$ males and $83(6.7 \%)$ females. The mean age of the donors was $30 \pm 7.4$ years (range $18-62$ years) and their mean packed cell volume was $43.3 \pm 3.0 \%$. Ninety-eight percent (1216) were replacement donors while $2.0 \%$ (25) were voluntary donors. Fifty-one $(4.1 \%)$ were reactive to HCV antibody. 
HCV infection occurred significantly high $1.7 \%(\mathrm{n}=21)$ in donors aged $30-41$ years. Table I.

Table I: Hepatitis $\mathrm{C}$ antibody seropositivity according to age groups among blood donors

\begin{tabular}{lccc}
\hline Age groups & Positive n (\%) & Negative n (\%) & p-value \\
\hline $18-29$ & $10(0.8)$ & $533(42.9)$ & \\
$30-41$ & $21(1.7)$ & $441(35.5)$ & \\
$42-53$ & $11(0.9)$ & $206(16.7)$ & 0.0001 \\
$54-65$ & $9(0.7)$ & $10(0.8)$ & \\
\hline Total & $\mathbf{5 1 ( 4 . 1 )}$ & $\mathbf{1 1 9 0}(\mathbf{9 5 . 9 )}$ & \\
\hline
\end{tabular}

Of the $51 \mathrm{HCV}$ positive donors, $46(90.2 \%)$ were males while $5(9.8 \%)$ were females. This gender difference was not statistically significant. $(\mathrm{P}=0.156)$. Blood group $\mathrm{O}$ Rhesus positive donors had the highest frequency of $\mathrm{HCV}$ infection of $3.3 \%(\mathrm{n}=41)$, followed by blood group A positive with $0.4 \%(\mathrm{n}=5)$.

Donors with PCV values between 43-50\% had the highest HCV infection 31 (2.5\%). But HCV infection was shown not to be dependent on haematocrit level. $(\mathrm{p}=0.099)$. Family replacement donors had HCV infection rate of $50(4.03 \%)$ while voluntary donor accounted for $1(0.07 \%)$. This difference was not statistically significant. Table II.

Table II: HCV seropositivity according to PCV level and type of Blood donor

\begin{tabular}{lccc}
\hline Characteristics & Positive n $(\%)$ & Negative n (\%) & P-value \\
\hline $\begin{array}{l}\text { Haematocrit }(\%) \\
34-42\end{array}$ & $20(0.16)$ & $510(41.1)$ & \\
$43-50$ & $31(2.5)$ & $658(53.0)$ & \\
$51-59$ & $0(0)$ & $22(1.8)$ & 0.099
\end{tabular}

Type of blood donation

$\begin{array}{llll}\text { Voluntary Donor } & 1(0.4) & 24(1.9) & \\ \text { Family Replacement Donor } & 50(40.3) & 1190(96.0) & 0.976\end{array}$

\section{Discussion/Conclusion}

Blood is a life saving agent but its transfusion can result in life threatening infections to the recipient.5 Despite screening, HCV can still be transfused as a result of laboratory errors, use of less sensitive screening methods, presence of immunological variant viruses, and non-sero-converting chronic carriers. Very sensitive methods of detecting these disease agents have been developed, but they are not largely used in developing countries due to cost considerations. Our study centre is a new health facility that started operation 17 months prior to this study. This accounted for the low number of donors during the period of study. Male donors were more than female donors, as a result of physiological conditions that exclude women from blood donation, and these include monthly menstrual cycle, pregnancy and lactation. Only replacement and voluntary donors were encountered in this study, as it is the policy of the hospital not to accept blood from remunerated donors. Replacement donors were much more than voluntary donors as the hospital is yet to commence vigorous donor drives to encourage the public to donate freely to the health facility. However, replacement donors still comprise a large proportion of blood donors in many other parts of the world.6

The seroprevalence of Hepatitis C virus infection in the study centre is $4.1 \%$. This result is lower than the $17.8 \%$ recorded in similar study in Lahore, Pakistan7 and $13.6 \%$ in Egypt. 8 The high prevalence rate in Lahore, was 
attributed to the use of very sensitive third generation ELISA screening method as against the rapid kits used in our study.

Our result is however similar to the findings of Ryas et al 9 Rehman et al. 10, Asif et al. 11,Farooqi et al. 12, from other parts of Pakistan who reported the prevalenceof hepatitis $\mathrm{C}$ as $4.7 \%, 4.1 \%, 5.14 \%$ and $3.21 \%$,respectively. These latter studies use immune-chromatographic diagnostic technique as in our study. But in most of the earlier studies, an earlier generation of anti-HCV ELISA (which was less sensitive and less specific) was used.12

Mutimer et al.13 and Halim et al 14 had reported high seroprevalence rates of $12.3 \%$ and $14.0 \%$ respectively, but this was among commercial blood donors in Nigeria. These corroborate the high risk of this infection among commercial donors who should be discouraged from blood donations as it is done in many parts of the world.

Alao et al 15 had earlier in 2010 reported a 5.4\% rate of $\mathrm{HCV}$ antibody among blood donors in Makurdi, Benue State, North Central Nigeria. The decreasing trend of hepatitis $\mathrm{C}$ prevalence in this city as shown by our study may have resulted from behavioral changes that have led to decreased transmission of infection.

Lower prevalence of HCV among blood donors have been reported in North Region of Jordan16 0.8\%, 0.33\% for Saudi Arabia,17 1.8\% in India,18 1.3 in Egypt,19 0.95\% in Syria,20 and Turkey21 0.07\%. Several other studies22-29 have also reported lower HCV Seroprevalence in blood donors than our study. The differences in the prevalence between our study and other studies may be attributed to differences in the sensitivities of the assays used, the criteria of positivity, types of donors as well as in the degree to which individuals with risk factors for blood-borne viral infections may have been excluded.

Majority $(90.2 \%)$ of the $\mathrm{HCV}$ positive donors, were males. This gender difference was not statistically significant. The high ratio of male to female blood donors in this study has been documented in similar studies to other countries.30 Inyama et al 31 observed that males had higher HCV antibody prevalence than the females. Comparisons of the prevalence of $\mathrm{HCV}$ among different sex in blood donors may not be valid because of high percentage of male blood donors. The limitations the females face in blood donation are due to low hemoglobin in female and the fact that women are less willing to donate blood. Though few studies have shown HCV seropositivity to be significantly higher among the female donors. 32

The prevalence rate of hepatitis $\mathrm{C}$ was noted to be higher among older age group than among young age group.16 But the highest frequency of HCV infection of $1.7 \%(n=21)$ in our study was in donors aged 30-41 years. In a similar study at Nnewi, South East Nigeria, Odenigbo et al 33 reported the highest rate $(3.2 \%)$ of positive reaction occurring in the 31-40 years age bracket, while Buseriet al 34 in Osogbo South west Nigeria reported highest infection rate in the age range 18-47 years. It has been observed that, the prevalence rate of hepatitis $\mathrm{C}$ was generally higher among old donors than younger donors. This is confirmed by the results reported earlier by other investigators.16,35 This may be explained on the basis of increased exposure with age. But findings from our study, Odenigbo et al and Buseri et al are on the contrary.

\section{Conclusion:}

Our findings further confirmed the high prevalence of hepatitis $\mathrm{C}$ infection among blood donors in Makurdi, though the trend seems to be decreasing. We still recommended routine screening for HCV antibodies with more sensitive diagnostic methods such as nucleic acid amplification testing (NAT) in order to further reduce the risk of post transfusion hepatitis $\mathrm{C}$. We also advocate follow up on blood donors who tested positive to reduce the probability of transmission, preventing further spread in the community.

\section{References}

[1]. Kalepoto G.N., Bhally H.S., Khaliq G. Epidemiology of blood-borne viruses. A study of health blood donors in southern Pakistan. J. Pak. Med. Assoc., 1996; 27: 703-6.

[2]. Kato N: Genome of human hepatitis C virus (HCV), gene organization, sequence diversity, and variation. Microb Comp Genomics 2000, 5(3):129-51.

[3]. Allain JP, Candotti D, et al. The risk of hepatitis B virus infection by transfusion in Kumasi, Ghana. Blood 2003; 101: 6: 24192425

[4]. Dhar G, Sarkar AP, Sen S, Ghosh S, Mukhopadhyay BB, Ghosh TK. Patterns of infective sero positivity among blood donors in a rural Medical College Regional Blood Transfusion centre: A retrospective study. Nepal Journal of Medical Sciences 2013;2(1):3-8.

[5]. Nanda A, Tyagi S, Basu S, Marwaha N. Prevalence of transfusion transmitted infections among voluntary and replacement donors. Indian J Hemat Blood Transf, 2001;19:104-5

[6]. Abdul Majeed Akhtar, M. Athar Khan, Tayyaba Ijaz, Zafar Iqbal, Muhammad Younus, Rana, Azhar Maqbool and Abdul Rehman. Seroprevalence and Determinants of Hepatitis-C Virus Infection in Blood Donors of Lahore, Pakistan. Pakistan J. Zool., vol. 45(1), pp. 1-7, 2013.

[7]. Soheir AE et al. Prevalence of anti-HIV, HBsAg and anti-HCV 13 reactivity in different categories of Egyptian blood donors: experience of the National Cancer Institute in the last 5 years. Journal of the Egyptian National Cancer Institute. 2002, (3):217221.

[8]. Ryas, M., Hussain, T., Bhatti, F.A., Ahmad, F,Tariq, W.U. And Khattack, M.F, Epidemiology of hepatitis C virus infection in blood donors in Northern Pakistan. J. Rawalpindi med. Coll., 2001, 5: 56-59. 
[9]. Rehman, M.U., Akhtar, G.N. And Lodhi, Y, Seroprevalence of hepatitis C antibodies in blood donors. Pak. J. med. Sci., 2006.18: 193-196.

[10]. Asif, N., Kokhar, N. And Ilahi, F.,. Seroprevalence of HBV, HCV and HIV infection among voluntary non remunerated and replacement donors in Northern Pakistan. Pak. J. med. Sci. 2004 20: 24-8.

[11]. Farooqi, J.I., Farooqi, R.J. And Khan, N.M., Frequency of hepatitis B and C in selected groups of populations in NWFP, Pakistan. J. Postgrad. med. Ins., 2007. 21: 165-168

[12]. Booth, J.C., 1998. Chronic hepatitis C: the virus, its discovery and natural history of the disease. J. Viral Hepatitis, 5: 213-22.

[13]. Halim, N.K. and O.I. Ajayi, 2000. Risk factors and seroprevalence hepatitis C antibody in blood donors in Nigeria. East African Medical J., 77: 410-12.

[14]. Alao OO, Okwori EE, Araoye MO. The sero-prevalence of hepatitis C virus infection among prospective blood donors in Makurdi, Nigeria. The internet J. infect. 2010. Dis. 8: DOI: 10.5580/1d2e.

[15]. Fathi Abed Al-Gani, Rashed Ben Al-Hassan Prevalence of HBV, HCV and HIV-1, 2 infections among blood donors in Prince Hospital in North Region of Jordan. Int J Biol Med Res. 2011; 2(4): 912 - 916

[16]. Mehdi SR, Pophali A, Al-Abdulrahim KA. Prevalence of hepatitis B and C among blood donors. Saudi Med J. 2000; 21: 942-944.

[17]. Nanu A, Sharma SP, Chatterjee K, Jyoti P. Markers for transfusion transmissible infections in North Indian voluntary and replacement blood donors. Prevalence and Trends. 1989-1996. Vox Sang 1997; 73:70-73.

[18]. Darwish MA, Raouf TA, Rushdy P, Constantine NT, Rao MR, Edelman R. Risk factors associated with a high seroprevalence of hepatitis C virus infection in Egyptian blood donors. Am J Trop Med Hyg. 1993; 49: 440-447

[19]. Othman BM, Monem FS. Prevalence of hepatitis C virus antibodies among intravenous drug abusers and prostitutes in Damascus, Syria. Saudi Med J. 2002; 23: 393-395.

[20]. Gurol E. Trends in hepatitis B and hepatitis C virus among Blood donors over 16 years in Turkey. European Journal of Epidemiology,2006, 21:299-305.

[21]. Bala JA, Kawo AH, Muktar MD, Sark A, Magaji W, Aliyu LA, Sani MA. Prevalence of hepatitis C infection among blood donors in some selected hospitals in Kano, Nigeria. Intern. Res. J. Microbiol.2012 3: 217-22

[22]. Glynn SA, Kleinman SH, et al. Trends in incidence and prevalence of major transfusion-transmissible viral infections in US blood donors, 1991 to 1996. JAMA 2000; 284:2:229-235

[23]. Vivas-Arceo C, Benavides SA, et al. Hepatitis C virus: prevalence and routes of infection among blood donors of West Mexico. Hepatology Research 2003; 25:115-123

[24]. Tanim H, Irani-Hakime N, et al. Seroprevalence of Hepatitis C virus (HCV) infection among blood donors: a hospital-based study. Transfusion and Apheresis Science 2001; 24: 29-35

[25]. Luksamijarulkul P, Thammata N, Tiloklurs M. Seroprevalence of hepatitis B, hepatitis C and human immunodeficiency virus among blood donors, Phitsanulok regional blood center, Thailand. Southeast Asian J TropMed Public Health 2002. 33:272-9.

[26]. Prevalence of hepatitis $b$ and hepatitis cIn blood donors of Karachi. E:/Biomedica Vol.24, Jul. - Dec. 2008/Bio-9.Doc (WC) P. 116-117

[27]. Ahmed J. Frequency of Hepatitis B and C in Healthy blood donors of NWFP: a single center experience. J. Post Grad. Med. Inst. 2004; 18 (3): 343-52.

[28]. Ishtiaq A.C. et al. Seroprevalence of Hepatitis B and C among the healthy donors at Fauji Foundation Hospital, Rawalpindi. Pak. J. Med. Sci. 2007; 23

[29]. Epidemiology, biostatistics and preventive medicine, 2nd ed. Philadelphia, WB Saunders, 2001

[30]. Inyama, P.U., C.J. Uneke, G.I. Anyanwu, O.M. Njoku, J.H. Idoko, J.A. Idoko, 2005. Prevalence of Antibodies to Hepatitis C virus among Nigerian Patients with HIV Infection. Online J. Health and Allied Sci., 2: 2. www.ojhas.org/issue14/2005-2-2.htm. Retrieved 2009

[31]. Jeremiah ZA, Kaote B, Buseri F, Emelike F (2008). Prevalence of antibodies to hepatitis C virus in apparently healthy Port Harcourt blood donors and association with blood groups and other risk indicators. Blood Transfus. 6:150-155

[32]. Odenigbo C, Oguejiofor C, Okonkwo U, Asamugha A, Ezeh T, Okocha E. Prevalence of antibodies to hepatitis C virus in blood donors in Nnewi, South East Nigeria: in association with blood groups. The Intern. J. Gastroenterol. 2010. 10: 10.5580/1c70.

[33]. Buseri FI, Muhibi MA, Jeremiah ZA (2009). Sero epidemiology of transfusion transmissible infections among blood donors in Osogbo, Southwest Nigeria. Blood Transfus. 7: 293-297

[34]. Sarkodie F, Adarkwa M, Adu-Sarkodie Y, Candotti D, Acheampong JW, Allain JP. Screening for viral markers in volunteer and replacement blood donors in West Africa. Vox Sang. 2001; 80: 142-147. 